\title{
Hyperoxia in intensive care, emergency, and peri-operative medicine: Dr. Jekyll or Mr. Hyde? A 2015 update
}

\author{
Sebastian Hafner ${ }^{1,2}$, François Beloncle ${ }^{3,4}$, Andreas Koch ${ }^{5,6}$, Peter Radermacher ${ }^{1 *}$ and Pierre Asfar $r^{3,4}$
}

\begin{abstract}
This review summarizes the (patho)-physiological effects of ventilation with high $\mathrm{FiO}_{2}(0.8-1.0)$, with a special focus on the most recent clinical evidence on its use for the management of circulatory shock and during medical emergencies. Hyperoxia is a cornerstone of the acute management of circulatory shock, a concept which is based on compelling experimental evidence that compensating the imbalance between $\mathrm{O}_{2}$ supply and requirements (i.e., the oxygen dept) is crucial for survival, at least after trauma. On the other hand, "oxygen toxicity" due to the increased formation of reactive oxygen species limits its use, because it may cause serious deleterious side effects, especially in conditions of ischemia/reperfusion. While these effects are particularly pronounced during long-term administration, i.e., beyond 12-24 h, several retrospective studies suggest that even hyperoxemia of shorter duration is also associated with increased mortality and morbidity. In fact, albeit the clinical evidence from prospective studies is surprisingly scarce, a recent meta-analysis suggests that hyperoxia is associated with increased mortality at least in patients after cardiac arrest, stroke, and traumatic brain injury. Most of these data, however, originate from heterogenous, observational studies with inconsistent results, and therefore, there is a need for the results from the large scale, randomized, controlled clinical trials on the use of hyperoxia, which can be anticipated within the next 2-3 years. Consequently, until then, "conservative" $\mathrm{O}_{2}$ therapy, i.e., targeting an arterial hemoglobin $\mathrm{O}_{2}$ saturation of 88-95\% as suggested by the guidelines of the ARDS Network and the Surviving Sepsis Campaign, represents the treatment of choice to avoid exposure to both hypoxemia and excess hyperoxemia.
\end{abstract}

\section{Background}

The "double-edged sword" character of molecular oxygen $\left(\mathrm{O}_{2}\right)$ is well established and has been a matter of debate since its discovery at the end of the eighteenth century. On the one hand, $\mathrm{O}_{2}$ plays a crucial role during adenosine triphosphate (ATP) synthesis [1]. On the other hand, its chemical characteristics lead to strong oxidizing properties, capable of damaging any biological molecule [1], and thereby defining the paradigm of oxygen toxicity. This phenomenon is due to the formation of reactive oxygen species (ROS), its magnitude being directly correlated to the level of the $\mathrm{O}_{2}$ partial pressure $[2,3]$.

\footnotetext{
*Correspondence: peter.radermacher@uni-ulm.de

${ }^{1}$ Institut für Anästhesiologische Pathophysiologie und

Verfahrensentwicklung, Universitätsklinikum Ulm, Helmholtzstrasse 8-1,

89081 Ulm, Germany

Full list of author information is available at the end of the article
}

Moreover, during mitochondrial respiration, $1-3 \%$ of $\mathrm{O}_{2}$ consumption leads to ROS formation [3]. Like $\mathrm{O}_{2}$, ROS also exert Janus-headed properties: while being of importance for host defense and signaling cascades, their toxic effects are well known [4].

Circulatory shock is defined as "...an imbalance between $\mathrm{O}_{2}$ supply and requirements..." [5], and consequently, a logical therapeutic strategy is to increase the inspired $\mathrm{O}_{2}$ concentration $\left(\mathrm{FiO}_{2}\right)$. The recommendation that the administration of oxygen should be started immediately to increase $\mathrm{O}_{2}$ delivery [6] has been known for a long time as a part of the "V" ("ventilate") component of the "VIP" ("ventilate-infuse-pump") rule for shock resuscitation [6]. Due to this, supplemental $\mathrm{O}_{2}$ was an integral part of all resuscitation protocols of the recently published Protocolized Care for Early Septic Shock (ProCESS) trial [7]. However, literature data 
concerning the high-dose administration of $\mathrm{O}_{2}$ are still highly controversial [8-14]. Moreover, hyperoxia (i.e., an increased $\mathrm{FiO}_{2}$ ) must be distinguished from hyperoxemia (i.e. increased arterial $\mathrm{O}_{2}$ partial pressure): in patients with severe Acute Respiratory Distress Syndrome (ARDS), hyperoxia may be mandatory to avoid hypoxemia with the least mechanical ventilation-induced hemodynamic compromise and/or ventilator-induced damage to the lung possible. This is nicely demonstrated by the results of the ARDSNetwork trial on low tidal volume ventilation: the $\mathrm{FiO}_{2}$ was significantly higher in the group with lower tidal volumes that ultimately had improved survival [15]. Figure 1 [16] summarizes the key pro and con arguments concerning the use of $\mathrm{O}_{2}$ therapy during shock states. Data from prospective, controlled, randomized trials on the use of therapeutic hyperoxia, however, are surprisingly scarce. Consequently, given the possible deleterious side effects of hyperoxia, the current guidelines of the ARDSNetwork and the Surviving Sepsis
Campaign recommend using an $\mathrm{FiO}_{2}$ that allows achieving an arterial hemoglobin $\mathrm{O}_{2}$ saturation of $88-95 \%$ at airway plateau pressures and PEEP levels of $<30$ and $5-20 \mathrm{cmH}_{2} \mathrm{O}$, respectively $[15,17]$. The present review will, therefore, discuss the role of ventilation with high $\mathrm{FiO}_{2}(0.8-1.0)$ during circulatory shock, during medical emergencies and in the peri-operative period; the first part will briefly summarize the (patho)-physiological effects of hyperoxia, the second part will review its use in the context of important pathological entities, with a particular focus on the most recent clinical evidence.

\section{(Patho)physiology of hyperoxia: pulmonary,} vascular, metabolic, and cerebral effects

Blood $\mathrm{O}_{2}$ content

According to textbook physiology, increasing the $\mathrm{FiO}_{2}$ from 0.21 (i.e., air) to 1.0 (i.e., $100 \% \mathrm{O}_{2}$ ) will moderately affect total blood $\mathrm{O}_{2}$ content under conditions of normal cardiopulmonary function: at normal $\mathrm{pH}$ and

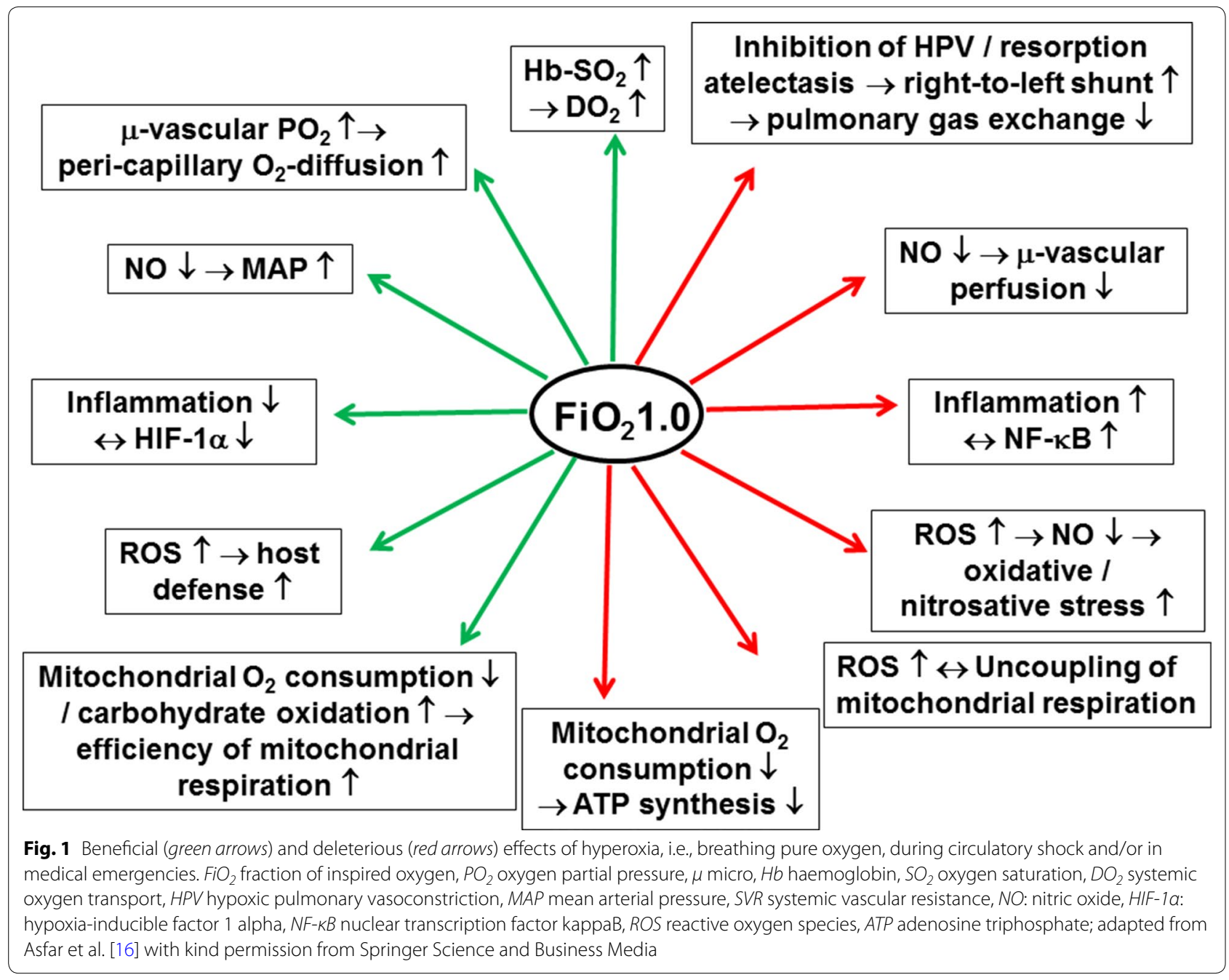


temperature, arterial $\mathrm{PO}_{2}$ levels of $90-100 \mathrm{mmHg}$ lead to hemoglobin $\mathrm{O}_{2}$ saturations close to $100 \%$ due to the sigmoid shape of the hemoglobin- $\mathrm{O}_{2}$-dissociation curve. Therefore, pure $\mathrm{O}_{2}$ breathing will only raise the amount of physically dissolved $\mathrm{O}_{2}$, the maximum effect being a five-fold increase, while hardly modifying the amount of $\mathrm{O}_{2}$ bound to hemoglobin. It is self-evident from the aforementioned estimate that the effect of pure $\mathrm{O}_{2}$ breathing on total blood $\mathrm{O}_{2}$ content will be the more important the lower the hemoglobin concentration. Therefore, ventilation with $100 \% \mathrm{O}_{2}$ was particularly protective in various models comprising critical hemodilution (reviewed in Calzia et al. [12]): the most impressive evidence in this context are the data reported in the "Live without blood" experiment as early as in 1960 [18]: in pigs subjected to hemodilution to a hematocrit $<1-2 \%$ (!), mechanical ventilation with pure $\mathrm{O}_{2}$ allowed preventing the otherwise marked ECG signs of myocardial ischemia, and no sequelae were observed after blood re-transfusion and return to air breathing. Strikingly, however, despite its frequent routine use, so far there are no clinical data on the role of mechanical ventilation with $\mathrm{FiO}_{2}=1.0$ during the management hemorrhagic shock, most likely due to ethical constraints. The available pre-clinical data are equivocal: deleterious and beneficial effects as well as no therapeutic efficacy at all were reported, depending on the species used, the severity of shock, and the concomitant use of therapeutic hypothermia [19-25].

No matter the definitive role of pure $\mathrm{O}_{2}$ breathing during situations of critical reductions in blood $\mathrm{O}_{2}$ transport capacity due to blood loss and/or hemodilution, pre-oxygenation, i.e., administration of $100 \% \mathrm{O}_{2}$ prior to induction of anesthesia and/or airway management, is well established to markedly increase the margin of safety: the "safe time of apnea" (i.e., the time until transcutaneous $\mathrm{O}_{2}$ saturation fell below $90 \%$ ) was doubled, when the $\mathrm{FiO}_{2}$ was increased from 60 to $100 \%$ [26]. It must be noted, however, that even short-term pure $\mathrm{O}_{2}$ ventilation under these conditions may be associated with formation of atelectasis (see below). In healthy, non-obese patients with American Society of Anesthesiologists physical status I or II, this atelectasis formation was prevented by using an $\mathrm{FiO}_{2}$ of 0.8 , but the safe time of apnea was significantly shorter [26]. Unfortunately, there is no ideal $\mathrm{FiO}_{2}$, which allows achieving a maximum "safe time of apnea" with the least formation of atelectasis [27, 28]: the degree of the latter depends on the patients' age [29], body mass index [30], and underlying chronic pulmonary co-morbidity [31].

Interestingly, this concept of a prolonged margin of safety seems to be valid in coronary artery disease for $\mathrm{O}_{2}$ breathing as a preventive, pre-treatment measure: breathing $15 \mathrm{~L} / \mathrm{min} \mathrm{O}_{2}$ prevented the recurrence of pacing- [32] and prolonged the time until occurrence of exercise-induced angina [33].

\section{Pulmonary effects}

Pure $\mathrm{O}_{2}$ breathing impairs pulmonary gas exchange as a result of inhibition of hypoxic pulmonary vasoconstriction induced by the rise in alveolar and mixed-venous $\mathrm{PO}_{2}$ [34, 35]. Moreover, as already mentioned-above, within a few minutes, e.g., after only 5 min of apnea and oxygenation during induction of anesthesia [26], pure $\mathrm{O}_{2}$ breathing causes formation of atelectasis with increased intrapulmonary right-to-left shunt. This "adsorption atelectasis" [36, 37] is due to instability of lung regions that are still open but poorly ventilated in relation to perfusion, so-called low ventilation/perfusion-ratio $\left(\mathrm{V}_{\mathrm{A}} / \mathrm{Q}\right)$ regions [38], when the inert carrier gas $\mathrm{N}_{2}$ is washed out. In healthy volunteers, breathing $100 \% \mathrm{O}_{2}$ over approx. 25 min under normobaric conditions doubled intrapulmonary right-to-left shunt, while breathing air at equal inspiratory $\mathrm{O}_{2}$ partial pressure, i.e., in a hyperbaric chamber pressurized to 4.9 atmospheres of ambient pressure, did not affect gas exchange [12]. During induction of anesthesia, this atelectasis formation was prevented at least in part by using CPAP breathing and subsequent face mask ventilation with a PEEP of $6-10 \mathrm{cmH}_{2} \mathrm{O}[39$, 40]. In mechanically ventilated patients with acute lung injury, the degree of hyperoxia-induced adsorption atelectasis could at least be attenuated by using higher PEEP levels: increasing PEEP from 5 to $14 \mathrm{~cm} \mathrm{H}_{2} \mathrm{O}$ completely blunted the fall of the $\mathrm{PaO}_{2} / \mathrm{FiO}_{2}$ ratio from 200 to $150 \mathrm{~mm} \mathrm{Hg}$ induced by increasing the $\mathrm{FiO}_{2}$ from 0.6 to 1.0 [37].

Acute hyperoxia-induced impairment of gas exchange must be discriminated from pulmonary $\mathrm{O}_{2}$ toxicity [41, 42], the so-called Lorrain-Smith effect [43] first described by Lavoisier in 1783 [44]. Pulmonary $\mathrm{O}_{2}$ toxicity may present as severe pulmonary inflammation, ultimately leading to hemorrhagic pulmonary edema, and is referred to excess ROS and reactive nitrogen species (RNS) formation [45, 46]. However, despite the abundant evidence on hyperoxia-induced acute lung injury from studies in experimental animal (for reviews see $[45,47])$, so far no biomarkers have been identified in humans that would allow evaluating the degree of ROS and/or RNS formation, and, moreover, thereby avoiding pulmonary $\mathrm{O}_{2}$ toxicity. Consequently, albeit intuitively being a logical therapeutic approach, there are no large scale data on the prevention of pulmonary $\mathrm{O}_{2}$ toxicity by ROS scavengers in humans, similar to the equivocal role of antioxidants in critically ill patients in general $[48,49]$. In healthy experimental animals, pulmonary $\mathrm{O}_{2}$ toxicity is a result of either long-term exposure and/or injurious ventilator settings leading to ventilator-induced 
lung injury (VILI) (for examples, see $[50,51]$ ). In contrast, lung-protective ventilation using low tidal volumes with higher PEEP levels and/or titrated to the thoracopulmonary compliance curve [52] over shorter periods had no deleterious effect at all [53], and this was also true during $24 \mathrm{~h}$ of lung-protective ventilation at $\mathrm{FiO}_{2}$ 1.0 in in large animals $[25,54]$. In humans, the duration of pure $\mathrm{O}_{2}$ breathing needed to provoke pulmonary $\mathrm{O}_{2}$ toxicity is unknown [55]: various studies reported that exposure period of 6-25 h were associated with clinical and histological signs of tracheitis and/or alveolitis [45, $56,57]$, whereas other authors suggested that "...direct oxygen toxicity only plays a negligible role in regards to perioperative administration.." [58] and that breathing an $\mathrm{FiO}_{2}$ of $0.96-1.0$ for $48 \mathrm{~h}$ does not produce symptoms of toxicity in most men $[45,59]$. The only data available from mechanically ventilated ICU patients originate from mechanical ventilation with $\mathrm{FiO}_{2}>0.85-0.9$ for $>10$ days $[60,61]$, and $\mathrm{FiO}_{2}=1.0$ over $14 \mathrm{~h}$ to 30 days $[62,63]$, respectively. Unfortunately, the studies do not report ventilator settings, but, given the publication years (1967-1972), it is unlikely that low tidal volumes and high PEEP levels according to current guidelines were used. Two more recent studies yielded equivocal results: observational data from patients mechanically ventilated for $>48 \mathrm{~h}$ with "excessive inspired $\mathrm{O}_{2}$ " (defined as an " $\mathrm{FiO}_{2}>0.5$ while maintaining $\mathrm{SO}_{2}>92 \%$ " observed in 155 out of 210 patients during a 12 -month observation period) showed significantly lower $\mathrm{PaO}_{2} / \mathrm{FiO}_{2}$ ratio and higher mean airway pressures at $48 \mathrm{~h}$ [64]. In contrast, retrospective analyses of patients after cardiac arrest showed that higher quartiles of the "area under curve of $\mathrm{FiO}_{2}$ " were not associated with any effect on gas exchange or lung mechanics during the first $24 \mathrm{~h}$ of mechanical ventilation [65]. Nevertheless, in this study the highest quartile of the "area under curve of $\mathrm{FiO}_{2}$ " coincided with decreased survival to hospital discharge and worse neurological outcomes. Hence, no threshold value for the duration of hyperoxia exposure leading to pulmonary $\mathrm{O}_{2}$ toxicity is known in mechanically ventilated patients. Most likely, defining such a threshold is per se impossible: it is well known from hyperbaric (patho)physiology that intermittent exposure to hyperoxia with interspersed short periods of air breathing markedly attenuates pulmonary $\mathrm{O}_{2}$ toxicity when compared to an equally long, but continuous exposure [66]. The problem of defining a threshold value for the initiation of pulmonary $\mathrm{O}_{2}$ toxicity was highlighted during the discussion of "Oxygen" during the 50th Respiratory Care Journal Conference held April 13-14, 2012, in San Francisco, CA: “...oxygen toxicity is like Bigfoot: everybody's heard about it, but nobody's ever seen it..." [45].

\section{Vascular effects}

Hyperoxia decreases cardiac output, on the one hand due to a fall in heart rate caused by increased parasympathetic tone [67], on the other hand due to a rise in systemic vascular resistance [68-70]. The latter may result from decreased ATP release from red blood cells [71] and/or reduced NO bioavailability. Stamler et al. elegantly demonstrated that the hyperoxia-induced increase in tissue and, consequently, venous $\mathrm{PO}_{2}$ levels blocks the release of NO from cystein-binding in the hemoglobinmolecule ( $S$-nitrosothiol) [72]. In addition, increased ROS formation contributes to hyperoxia-induced vasoconstriction: administration of vitamin C (200 mg intraarterial [69] and $3 \mathrm{~g}$ intra-venous [73], respectively), restored forearm [69] and coronary vascular resistance [73]. While varying among the different vascular regions, the degree of the hyperoxia-induced vasoconstriction is particularly pronounced in the cerebral and coronary circulation. Therefore, it was argued that this hyperoxiarelated vasoconstriction may impede tissue $\mathrm{O}_{2}$ delivery in patients with sepsis [74] or cardiovascular disease [75], but it is still a matter of debate whether the hyperoxiainduced vasoconstriction is beneficial or deleterious: in fact, 30 min of pure $\mathrm{O}_{2}$ breathing impaired the sublingual microcirculatory perfusion by decreasing the number and density of perfused vessels, while it even increased perfusion heterogeneity [76]. It must be noted, however, that most of the studies available in the literature on hyperoxia-induced systemic or regional vasoconstriction were performed in healthy volunteers or at least under stable hemodynamic conditions, i.e., without imbalance between $\mathrm{O}_{2}$ supply and demand, or, during circulatory shock. In addition, any hyperoxia-related increase in vasomotor tone could possibly allow reducing vasopressor demands required to counteract shock-induced hypotension. Finally, experimental data suggest that pure $\mathrm{O}_{2}$ ventilation may redistribute cardiac output in favor of the kidney and the hepato-splanchnic system and thereby improve visceral organ function [25, 54, 77]. Yet, scarce data are only available on the effects of ventilation with $\mathrm{FiO}_{2}=1.0$ on systemic or regional hemodynamics and organ function in patients with circulatory shock. Only one prospective pilot study, including 83 patients admitted to the emergency department with two or more systemic inflammatory response syndrome (SIRS) criteria and a suspected infection, i.e., sepsis, reported no association between in-hospital mortality and hyperoxia $\left(\mathrm{FiO}_{2}\right.$ between 0.4 and 0.8 ) [78], but only three patients with septic shock were included in total. Therefore, the results of the prospective, randomized, controlled HYPER2S (NCT01722422) trial (see Table 1) will certainly help to answer this question. 
Table 1 Clinical trials on the effects of hyperoxia in intensive care and emergency medicine

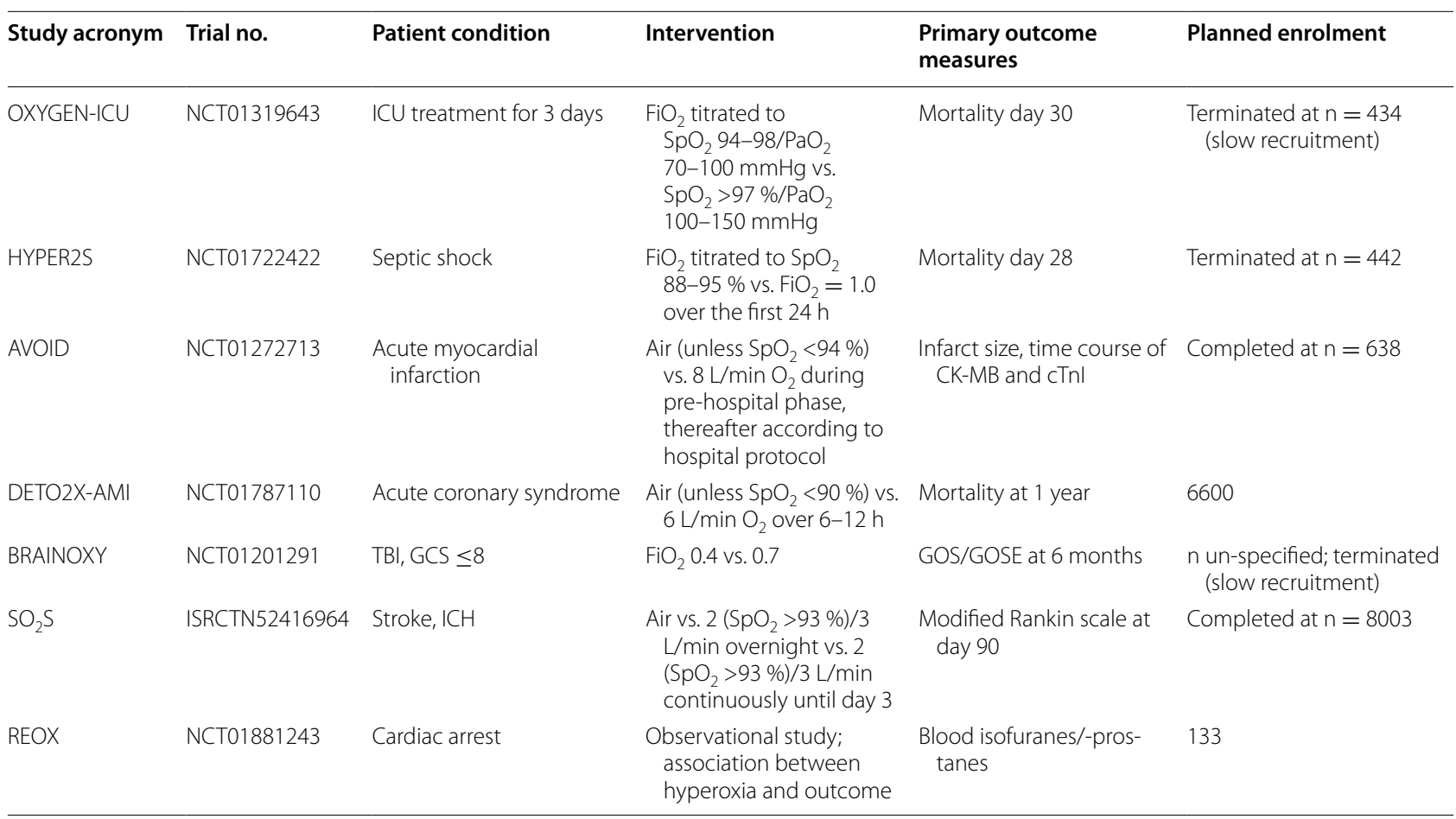

ICU intensive care unit, $\mathrm{FiO}_{2}$ fraction of inspired $\mathrm{O}_{2}$ concentration, $\mathrm{SpO}_{2}$ transcutaneous hemoglobin $\mathrm{O}_{2}$ saturation, $\mathrm{PaO}$ arterial $\mathrm{O}_{2}$ partial pressure, $\mathrm{CK}$ - $\mathrm{MB}$ myocardial creatine kinase, CTnI cardiac troponin I, TBI traumatic brain injury, GCS Glasgow Coma Score, GOS Glasgow Outcome Score, GOSE Extended Glasgow Outcome Score

\section{Metabolic effects}

No matter the definitive effect of hyperoxia on vascular tone during circulatory shock, any conclusion on the role of hyperoxia-induced vasoconstriction must be considered in the context of the effects of hyperoxia on metabolic activity. Clearly, in vitro long-term $(\geq 24 \mathrm{~h})$ exposure to hyperoxia was associated with impaired mitochondrial respiratory capacity as a result of partial inhibition of NADH and succinate dehydrogenase, i.e., complex I and II [79, 80], whereas cytochrome c oxidase (complex IV) remained unaffected [79]. Pure $\mathrm{O}_{2}$ breathing also decreased whole body $\mathrm{O}_{2}$ uptake in healthy volunteers $[76,81]$ as well as in critically ill patients [70, 82], and myocardial $\mathrm{O}_{2}$ consumption in patients with coronary artery disease [83]. Nevertheless, this reduced $\mathrm{O}_{2}$ uptake more likely mirrored decreased $\mathrm{O}_{2}$ demand rather than impaired $\mathrm{O}_{2}$ utilization: There was no deleterious effect on any marker of systemic energy balance [70, 82], and myocardial lactate extraction was even enhanced [83]. Moreover, studies in experimental animals [25, 54] and healthy volunteers [81] showed that hyperoxia increased the respiratory quotient to values close to 1.0, in other words suggesting that hyperoxia shifted energy metabolism to preferential utilization of carbohydrates $[25,54]$, which is well established to increase the yield of the mitochondrial respiratory chain [84], i.e., the molar ratio of $\mathrm{O}_{2}$ consumption and ATP formation [85]. Similar to the situation during exercise in highlanders [86], this effect might assume particular importance under conditions of limited tissue $\mathrm{O}_{2}$ supply, e.g., hemorrhagic and/ or cardiogenic shock.

\section{Cerebral effects}

In addition to the above-mentioned pulmonary toxicity, pure $\mathrm{O}_{2}$ breathing may also have toxic effects on the central nervous system, the so-called Paul-Bert effect [87], the most dramatic manifestation being generalized tonic-clonic (grand mal) seizures [11]. This central nervous toxicity, however, requires pure $\mathrm{O}_{2}$ breathing under supra-atmospheric pressures, i.e., during diving and/or in a hyperbaric chamber. Hence, only critically ill patients treated with hyperbaric oxygenation (HBO: pure $\mathrm{O}_{2}$ breathing at supra-atmospheric pressures; e.g., for decompression injury (DCI), gas embolism, carbon monoxide $(\mathrm{CO})$ poisoning, and gas gangrene or necrotizing fasciitis) will present with central nervous $\mathrm{O}_{2}$ toxicity-induced convulsions, which occur within approx. 20-30 min of pure $\mathrm{O}_{2}$ exposure at ambient pressures of three atmospheres. Interestingly, in contrast to the cerebral vasoconstriction normally observed during pure $\mathrm{O}_{2}$ breathing, symptoms are preceded by a paradoxical increase in cerebral blood flow velocity [88] (Fig. 2), 


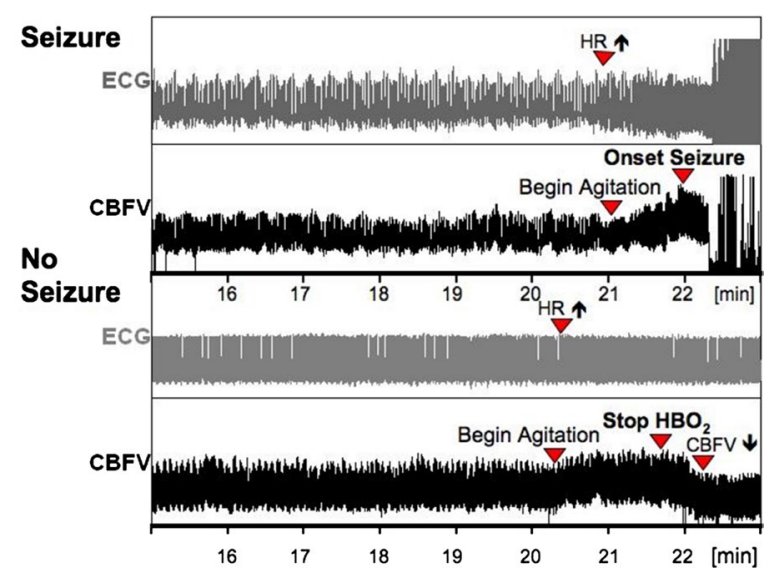

Fig. 2 Original recordings of ECG and cerebral blood flow velocity (CBFV) in two volunteers undergoing an $\mathrm{HBO}$ exposure-test with pure $\mathrm{O}_{2}$ breathing at three atmospheres of ambient pressure. In the upper panel, $\mathrm{HBO}$-induced seizures were preceded by tachycardia, agitation, and a subsequent marked increase in CBFV. The lower panel shows a volunteer, in whom seizures could be prevented by removing the $\mathrm{O}_{2}$ face mask; CBFV consecutively fell to lower levels comparable to those during the asymptomatic period

which is referred to peroxynitrite $\left(\mathrm{ONOO}^{-}\right)$formation resulting from the reaction of $\mathrm{NO}$ with the superoxide radical $\left(\mathrm{O}_{2}{ }^{-}\right)$[89], and thereby causing a dysregulation of the endogenous $\mathrm{NO}$ availability $[46,90]$.

\section{Clinical application of hyperoxia CO intoxication, gas embolism, and DCI}

No matter any possible deleterious effects related to enhanced ROS and RNS formation, pure $\mathrm{O}_{2}$ breathing is the therapy of choice during $\mathrm{CO}$ intoxication, gas embolism, and DCI. While the beneficial effect of hyperoxia during $\mathrm{CO}$ intoxication is related to the competitive replacement of $\mathrm{CO}$ in heme moieties, the salutary role of $\mathrm{O}_{2}$ during DCI and/or gas embolism is due to the socalled oxygen window effect.

Recent reports show that approx. $1 \%$ of patients admitted to emergency departments present with occult CO-intoxications [91]. CO has a several-fold higher affinity to heme moieties than $\mathrm{O}_{2}$, and thus it reduces the blood $\mathrm{O}_{2}$ transport capacity by preventing hemoglobin (Hb) $\mathrm{O}_{2}$ saturation. This effect on tissue $\mathrm{O}_{2}$ transport is further aggravated by the leftward-shift of the $\mathrm{Hb}$ $\mathrm{O}_{2}$-dissociation curve, which impairs $\mathrm{O}_{2}$ release from oxy-hemoglobin [92]. Nevertheless, CO toxicity is mainly due to the blockade of complex IV of the mitochondrial respiratory chain (i.e., cytochrome c oxidase) [93]. Ultimately, this inhibition of mitochondrial respiration will result in oxidative and nitrosative stress [94], which also explains that pure $\mathrm{O}_{2}$ breathing is the therapy of choice in patients with $\mathrm{CO}$ intoxication: albeit at first glance paradoxical, increasing the $\mathrm{PO}_{2}$ in fact reduces rather than further increases ROS and RNS formation during $\mathrm{CO}$ intoxication [94], because high $\mathrm{O}_{2}$ concentrations will restore normal electron transport within the respiratory chain and thereby decrease radical production. The half-life of $\mathrm{CO}$ elimination is inversely related to the arterial $\mathrm{PO}_{2}$ [95], and therefore, intuitively, $\mathrm{HBO}$ therapy is indicated in patients with $\mathrm{CO}$-intoxication. However, the results of the available RCT are equivocal [96-98], and a recent meta-analysis concluded that normobaric hyperoxia is as efficient as $\mathrm{HBO}$, in part as a result of the $\mathrm{CO}$ elimination achieved with normobaric pure $\mathrm{O}_{2}$ breathing during patient transport to an HBO chamber [99].

By definition gas embolism is the-mostly iatrogenicentry of gas bubbles into the vascular system in general [100], whereas decompression injury (DCI) comprises medical disorders resulting from a decrease in ambient pressure (i.e., decompression) that results in intra- or extra-vascular bubble formation due to excess (i.e., supersaturation) inert gas (in most cases $\mathrm{N}_{2}$ ) tensions [101]. However, DCI can also cause arterial gas embolism due to introduction of alveolar gas emboli via cardiac shunts and/or pulmonary vessels, but more frequently presents as decompression sickness (DCS), which is caused by excess supersaturation during and after decompression [102]. Treatment is breathing $100 \% \mathrm{O}_{2}$, and, as far as DCI is concerned, in combination with recompression, i.e., HBO [103]. In addition to its ability to improve tissue oxygenation and attenuate inflammation, pure $\mathrm{O}_{2}$ breathing is therapy of choice because it maximizes the inert gas gradient from the tissues to the alveolar gas and thereby accelerates inert gas washout [102]. Moreover, it will enhance bubble resolution due to the increased inert gas diffusion gradient (i.e, the oxygen window) (Fig. 3 [103]).

\section{Acute coronary syndrome}

In 1940, supplemental $\mathrm{O}_{2}$ breathing was described as “... as an efficient method of relieving the intense pain which may accompany acute coronary thrombosis and as an important therapeutic adjunct in the symptomatic control of severe angina pectoris..." [104], and subsequently became a cornerstone of the management of the Acute Coronary Syndrome. However, due to the above-mentioned coronary vasoconstriction [83], which was also more recently demonstrated to be due to NO quenching [105] associated with oxidative and nitrosative stress [73], this approach has been questioned [106, 107], despite data from patients with acute decompensated heart failure showing no effect of the arterial $\mathrm{PO}_{2}$ on all-cause mortality [108]. Therefore, the latest guidelines of the European Resuscitation Council on the initial management of acute coronary syndromes recommend that an “... $\mathrm{O}_{2}$ saturation of $94-98 \%$, or $88-92 \%$ if the patient 

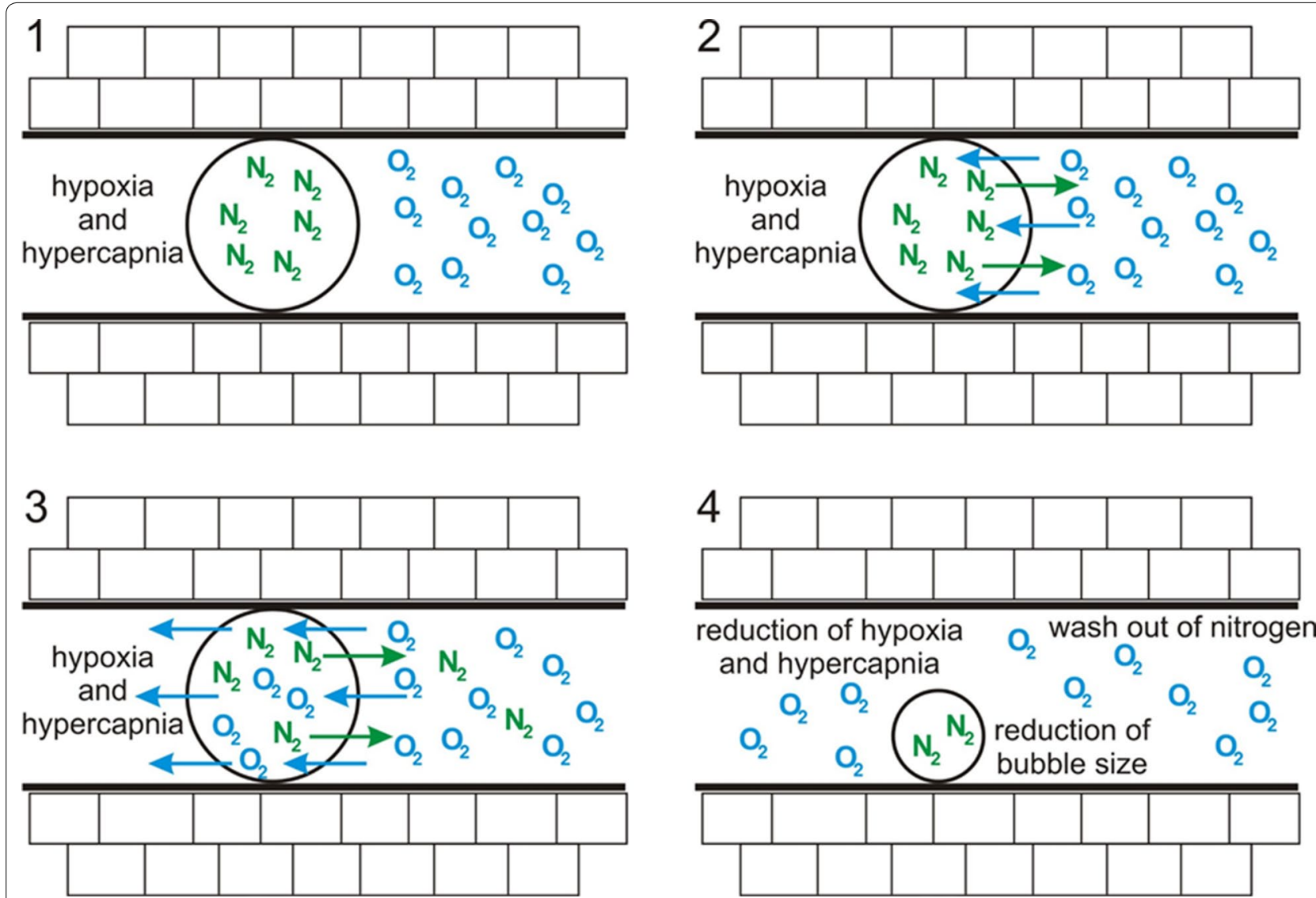

Fig. 3 Effect of increased oxygen partial pressure on bubble size. After creation of a concentration gradient (1), oxygen starts to diffuse into the bubble, simultaneously nitrogen diffuses out of the bubble (2). Thereby, oxygen molecules are now capable of passing the bubble with concomitant reduction of nitrogen concentration (3). Finally, the bubble size decreases significantly (4). Adapted from Muth et al. [103] with kind permission from Springer Science and Business Media

is at risk of hypercapnic respiratory failure..." should be achieved, in other words, "...supplementary $\mathrm{O}_{2}$ should be given only to those patients with hypoxaemia, breathlessness or pulmonary congestion..." [109]. Until most recently, the evidence for these guidelines was surprisingly scarce, because over four decades only four clinical trials enrolling a total of just 447 patients were published [110-113]. Moreover, the results of these trials were far from being conclusive: In 17 patients with anterior transmural myocardial infarction (MI), Madias et al. reported reduced ischemic injury as assessed by precordial ST-mapping during 48-80 min of breathing $15 \mathrm{~L} /$ min $\mathrm{O}_{2}$; however, this study did not include any control group [110]. In 157 patients with confirmed MI, Rawles et al. found no difference in the incidence of arrhythmias and use of analgesics after $6 \mathrm{~L} / \mathrm{min} \mathrm{O}_{2}$ over $24 \mathrm{~h}$ vs. air breathing; however, mortality in the $\mathrm{O}_{2}$-group tended to be higher without reaching statistical significance (3.9 vs. $11.3 \%, p=0.08$ ) [111]. More recently, in a total of 137 patients using two different protocols for supplemental
$\mathrm{O}_{2}$, Ukholkina et al. demonstrated that a $\mathrm{FiO}_{2}$ of $0.3-0.4$ until $3 \mathrm{~h}$ after interventional myocardial revascularization decreased the number of early post-intervention arrhythmia, which was associated with lower peak values of myocardial creatine kinase activity, and, ultimately, smaller relative area of ischemic damage. However, $37 \%$ of the patients had baseline $\mathrm{O}_{2}$ saturations $<94 \%$, i.e., below the threshold recommended for initiating supplemental $\mathrm{O}_{2}$ administration. Moreover, for reasons unexplained, time to revascularization was longer in the $\mathrm{O}_{2}$-group [112]. Finally, Ranchord et al. found “...no evidence of benefit or harm..." from high-concentration (6 $\mathrm{L} / \mathrm{min} \mathrm{O}_{2}$ over $6 \mathrm{~h}$ ) vs. titrated $\mathrm{O}_{2}$ therapy (to achieve $\mathrm{O}_{2}$ saturations of 93-96\%) in 136 patients with initially uncomplicated ST-elevation myocardial infarction [113]. Therefore, as highlighted in recent reviews [106, 107], there is urgent need for large clinical trials assessing whether or not $\mathrm{O}_{2}$ therapy should be used for the management of acute coronary syndrome, and the results of the DETO2X-AMI (NCT01787110) (see Table 1) trial 
is to answer this question. The most recently completed AVOID (NCT01272713) (see Table 1) trial has partly answered this need: in non-hypoxaemic (transcutaneous hemoglobin $\mathrm{O}_{2}$ saturation $>94 \%$ ) patients with STelevation myocardial infarction $(\mathrm{n}=441)$, high flow face mask $\mathrm{O}_{2}(8 \mathrm{~L} / \mathrm{min})$ up to $4 \mathrm{~h}$ after percutaneous coronary intervention increased myocardial injury, recurrent infarction, major cardiac arrhythmia, and late (6 months) myocardial infarct size. Mortality at hospital discharge did not significantly differ $(\mathrm{p}=0.11)$, but interestingly, was 2.5 fold higher in the normoxia group. At 6 months, however, both overall (hyperoxia: 3.8, normoxia: $5.9 \%$; $\mathrm{p}=0.32$ ) and cardiac (hyperoxia: 2.9 , normoxia $4.1 \%$ ) mortality were comparable [114].

\section{Traumatic and ischemic brain injury}

From a pathophysiological point of view, any hyperoxiainduced vasoconstriction could theoretically represent an interesting approach in the management of brain injury, inasmuch as it would allow reducing intracranial pressure (ICP) and thereby improving cerebral perfusion pressure without impairment of $\mathrm{O}_{2}$ supply. Clearly, $\mathrm{HBO}$ (60 min of mechanical ventilation with pure $\mathrm{O}_{2}$ at 1.5 atmospheres of ambient pressure was shown to efficiently decrease ICP in patients with traumatic brain injury (TBI) [115]. Combining $\mathrm{HBO}$ with subsequent normobaric hyperoxia even improved long-term outcome: at 6 months mortality was reduced ( 9 out of 22 vs. 3 out of 20 patients, $\mathrm{p}=0.048$ ), and overall neurological outcome was more favorable as evaluated with the sliding dichotomized Glasgow Outcome Score (8 out of 21 vs. 14 out of 19 patients, $\mathrm{p}=0.024$ ) [116]. However, normobaric hyperoxia alone yielded equivocal results with respect to tissue oxygenation and metabolism as assessed by microdialysis [117-122], which was referred to a lacking effect on brain tissue oxygenation in hypo-perfused regions [120] and/ or a possibly enhanced hyperoxia-related excitotoxicity [122]. Albeit there is some data available using magnetic resonance imaging (MRI), suggesting that hyperoxia may have a beneficial effect in the peri-lesional penumbra [123], the role of hyperoxia in TBI is still controversially discussed because of the equivocal outcome data [124]: while a uni-variate analysis found a significant association between hyperoxemia (arterial $\mathrm{PO}_{2}>100 \mathrm{mmHg}$ ) and a decreased risk of 6-month mortality in a retrospective analysis of 1116 patients, the corresponding multivariate logistic regression adjusted for illness severity did not show any significant relationship [125]. However, Davis and co-workers showed in a large retrospective cohort analysis including 3420 patients that both hypoxemia $\left(\mathrm{PaO}_{2}<110 \mathrm{mmHg}\right)$ and extreme hyperoxemia $\left(\mathrm{PaO}_{2}>487 \mathrm{mmHg}\right)$ were associated with increased mortality and unfavorable outcome among TBI patients
[126]. Moreover, two other retrospective studies analyzing a total of 1759 patients using multi-variate approaches showed that hyperoxemia defined as arterial $\mathrm{PO}_{2}>200$ or $>300 \mathrm{mmHg}$, respectively, was independently associated with increased mortality $[127,128]$. These data are in contrast to another retrospective study, reporting that oxygen partial pressures between 250 and $486 \mathrm{~mm} \mathrm{Hg}$ were associated with improved all-cause survival in patients with severe TBI [129]. So far, the answer to the question of the use of hyperoxia in TBI is still pending: the BRAINOXY study (NCT01201291), which was to answer this question, was terminated due to slow recruitment.

The currently available data on hyperoxia (with consecutive hyperoxemia) during ischemic brain injury, i.e., stroke and/or intracranial bleeding, is less conflicting: Albeit there is compelling experimental evidence (for review, see [130]) and some encouraging pilot data in patients [131, 132], evidence from large trials suggests that hyperox $(\mathrm{em})$ ia is deleterious. A prospective, singlecenter observational study in 252 patients showed that hyperoxemia (as defined as a $\mathrm{PaO}_{2}>173 \mathrm{mmHg}$ ) was associated with delayed cerebral ischemia and, consequently, poor neurological outcome [133]. In addition, a more recent retrospective analysis of 2894 mechanically ventilated patients with ischemic stroke, subarachnoid or intracerebral hemorrhage demonstrated that more pronounced hyperoxemia (arterial $\mathrm{PO}_{2}>300 \mathrm{mmHg}$ ) significantly increased in-hospital mortality at day 28 [134]. In contrast, a retrospective analysis of 2,643 adults, ventilated for ischemic stroke in ICUs in Australia and New Zealand, showed no apparent relationship between mortality and $\mathrm{PaO}_{2}$ levels during the first $24 \mathrm{~h}$ in ICU [135]. Finally, the Normobaric Oxygen Therapy in Acute Ischemic Stroke Trial (NCT00414726), which was to study the effects of high-flow $\mathrm{O}_{2}(30-45 \mathrm{~L} / \mathrm{min}$ for $8 \mathrm{~h}$ via facemask) was terminated prematurely after enrolment of 85 of 240 patients due to imbalance in deaths favoring the control arm (hyperoxia: 17 out of 43 patients, room air: 7 out of 42 patients, $p=0.03$ ). The question, however, whether hyperoxia is definitely deleterious, remained unanswered: deaths were not attributed to treatment by the blinded external medical monitor. No matter the impact of high-flow supplemental $\mathrm{O}_{2}$, even low-dose $\mathrm{O}_{2}$ administration $(2 \mathrm{~L} / \mathrm{min}$ either continuously over $72 \mathrm{~h}$ or over-night only) only targeted to compensate for mild, in particular nocturnal, hypoxemia (Stroke Oxygen Study, $\mathrm{SO}_{2} \mathrm{~S}$; ISRCTN52416964) did not improve outcome after ischemic stroke: despite promising pilot data in 289 patients at 1 week and 6 months [136, 137], the complete, full-scale study in 8003 patients did not show any difference in morbidity (disability at day 90 as assessed by the modified Rankin Scale) or mortality (data presented at the XXIII European Stroke Conference, Nice, May 7, 2014). 


\section{Cardiac arrest}

The pronounced vasoconstrictor effect in the cerebral circulation together with the potential to aggravate oxidative stress during ischemia/reperfusion have prompted investigations on the association between hyperox(em) ia and outcome after cardiopulmonary resuscitation. So far only retrospective analyses are available, except for one randomized controlled single centre trial including 28 patients in total, the results being again fairly equivocal: a multicenter cohort study on 6326 patients concluded that hyperoxemia defined as $\mathrm{PaO}_{2}>300 \mathrm{mmHg}$ was associated with higher mortality than normoxemia and even hypoxemia defined as $\mathrm{PaO}_{2}<60 \mathrm{mmHg}$ ) [138]. A secondary analysis of 4459 patients of this study even yielded a direct linear relationship between $\mathrm{PaO}_{2}$ incre-

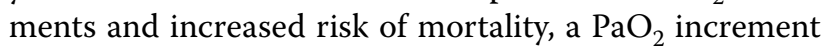
of $100 \mathrm{mmHg}$ being associated with a $24 \%$ higher odds ratio for unfavorable outcome [139]. Another retrospective analysis of 12,108 patients found no association between $\mathrm{PaO}_{2}$ deciles or hyperoxemia defined as $\mathrm{PaO}_{2}$ $>309 \mathrm{mmHg}$ and mortality adjusted for illness severity [140]. Other authors analyzing smaller data bases confirmed this latter finding [141, 142]. Clearly, different temperature management (lowest temperature: median $34.9{ }^{\circ} \mathrm{C}$ in [140] vs. mean $36{ }^{\circ} \mathrm{C}$ in [138]; 33 vs. $6 \%$ of patients $<34{ }^{\circ} \mathrm{C}$ ) in the various countries may have contributed to these divergent findings, albeit a singlecenter, retrospective analysis of 170 patients treated with therapeutic hypothermia $\left(12-24 \mathrm{~h}\right.$ at $32-34{ }^{\circ} \mathrm{C}$ core temperature) showed that mortality and poor neurological outcome were more frequent in patients with higher maximum $\mathrm{PaO}_{2}$ values (median 254 vs. $198 \mathrm{mmHg}$ ) during the first $24 \mathrm{~h}$ after cardiac arrest [143]. This is in line with another retrospective analysis in 213 patients after cardiac arrest, treated with therapeutic hypothermia, demonstrating a U-shaped independent association between the mean $\mathrm{PaO}_{2}$ and poor neurologic outcome at hospital discharge [144]. The sole randomized controlled trial, comparing 14 patients in each group ventilated with either 30 or $100 \%$ oxygen for $1 \mathrm{~h}$ after return of spontaneous circulation (ROSC), showed increased levels of neuron specific enolase in the hyperoxic group at $24 \mathrm{~h}$ post cardiac arrest [145]. Unfortunately, this study was not powered to analyze outcome parameters. Finally, other smaller studies focusing on the role of arterial $\mathrm{PCO}_{2}$ did not yield any deleterious effect of hyperoxemia per se on neurological outcome [146-148]. Consequently, a recent meta-analysis concluded that hyperoxemia $\left(\mathrm{PaO}_{2}\right.$ $>300 \mathrm{mmHg}$ ) "...appears to be correlated with increased in-hospital mortality...", which, however, "...should be interpreted cautiously because of the significant heterogeneity...of studies analyzed..." [149]. Lately, two more interesting retrospective cohort analyses reported that severe hyperoxia was associated with decreased survival as well as decreased survival and worse neurological outcome, respectively $[65,150]$. Nelskylä et al. offer an interesting explanation for the vast majority of retrospective studies being in favor of normoxia: In their retrospective analysis of 119 out of hospital cardiac arrest patients, hyperoxia occurred more frequently in association with out-of-hospital cardiac arrest, longer times to ROSC, and delays to ICU admission, i.e., the patients with the worst prognosis per se [142]. In addition, safe titration of oxygen therapy to achieve a $\mathrm{SpO}_{2}$ of 90-94\% after out-ofhospital cardiac arrest might not be feasible, at least in the pre-hospital period [151]. Taken together, all these studies demonstrate the urgent need for data from prospective, randomized controlled trials, and the ongoing REOX trial (NCT01881243) will at least help to answer this demand.

\section{Peri-operative hyperoxia}

The use of intra-operative (and, in a broader sense, perioperative) hyperoxia to prevent surgical site infection does not directly refer to the treatment of circulatory shock and medical emergencies, but patho-physiological effects of hyperoxemia also assume importance in this context. The antimicrobial properties of oxygen are due to the bactericidal properties associated with increased ROS production, and were already recognized in the 1980s ("oxygen as an antibiotic" [152]), subsequently prompting several clinical studies which have so far enrolled more than 5000 patients. Recent meta-analyses of these studies concluded that high inspired $\mathrm{O}_{2}$ concentrations values $\left(\mathrm{FiO}_{2}=0.8\right.$ vs. 0.3 as the standard approach) during the peri-operative period reduced the risk of surgical site infection, both after elective and emergency surgery, without leading to major post-operative atelectasis $[153,154]$. This protective effect was specifically present in non-obese patients undergoing colo-rectal surgery, one possible component being a better patency of anastomoses [155]. The molecular mechanisms of hyperoxia-related reduction in surgical site infection remain unclear: hyperoxic ventilation was reported to restore the local inflammatory response to normal-rather than leading to potentially deleterious hyper-inflammationthereby improving the antimicrobial potential of alveolar macrophages [156]. However, other authors found that ex vivo exposure to hyperoxia not only enhanced ROS formation but even decreased the capacity of endotoxinstimulated leukocytes to release tumor necrosis factor- $\alpha$ [157]. It is noteworthy that despite this short-term (up to 2 weeks within surgery) benefit, high intra-operative $\mathrm{FiO}_{2}$ was associated with higher long-term ( $>2$ years) post-operative mortality. This observation was nearly exclusively due to a higher mortilaty in patients that had 
undergone cancer surgery [158], and coincided with a significantly shorter cancer-free survival interval [159]. Therefore, and taking into account the trials showing no benefit for surgical site infection after abdominal surgery $[160,161]$, the most recent Cochrane analysis concluded that "...evidence is insufficient to support the routine use of a high fraction of inspired $\mathrm{O}_{2}$ during anesthesia and surgery...." [162].

\section{What is the optimal $\mathrm{PaO}_{2}$ for ICU survival?}

So far, this question remains unanswered as well: a retrospective analysis of arterial $\mathrm{PO}_{2}$ measurements in 36,307 patients during the first $24 \mathrm{~h}$ of ICU stay demonstrated a U-shaped relationship of in-hospital mortality, the nadir of the mortality curve (as calculated from the logistic regression with the $\mathrm{PaO}_{2}$ incorporated using a spline function) being at values of $15-20 \mathrm{kPa}(110-150 \mathrm{mmHg})$; mortality sharply increased both at $\mathrm{PaO}_{2}$ values $<9$ $(67 \mathrm{mmHg})$ and $>30 \mathrm{kPa}(225 \mathrm{mmHg})$ [163]. Interestingly, this group of authors recently showed a similar U-shaped relation between arterial $\mathrm{PCO}_{2}$ and $\mathrm{PO}_{2}$, respectively, and hospital mortality after cardiac arrest, the highest probability of survival being associated with a $\mathrm{PaO}_{2}$ values of $180-200 \mathrm{mmHg}$, i.e., most likely with an $\mathrm{FiO}_{2}$ $>0.6$ in a substantial number of patients [164]. A more recent study of unadjusted odds ratios for $\mathrm{PaO}_{2}$ deciles in 152,680 patients confirmed the impact of hypoxemia, whereas hyperoxemia even $>40 \mathrm{kPa}(300 \mathrm{mmHg})$ had no impact on outcome [165]. Finally, a retrospective cohort study including 83,060 patients after cardiac surgery showed that there was no association between mortality and hyperoxia in the first $24 \mathrm{~h}$ in ICU after cardiac surgery [166]. Therefore, two recent meta analyses concluded that hyperoxia may be associated with increased mortality in patients with stroke, TBI, and post cardiac arrest and with poor hospital outcome, respectively [167, 168]. However, due to heterogeneity of the included studies, the authors state that more evidence is needed to provide optimal oxygen targets for critical care physicians. The results of the OXYGEN-ICU (NCT01319643) trial (see Table 1) will certainly contribute to the answer of this question. Interestingly, most ICU clinicians acknowledge the potential adverse effects of prolonged exposure to hyperoxia, however, in actual clinical practice, a large proportion of their patients was exposed to higher arterial oxygen levels than self-reported target ranges [169].

\section{Conclusion}

Hyperoxia (i.e., ventilation with a $\mathrm{FiO}_{2}=1.0$ ) is a cornerstone of the acute management of circulatory shock, a concept which is based on compelling experimental evidence that compensating the imbalance between $\mathrm{O}_{2}$ supply and requirements (i.e., the oxygen dept) is crucial for survival, at least after trauma [170,171]. On the other hand oxygen toxicity due to the increased formation of ROS limits its use, because it may cause serious deleterious side effects, especially in conditions of ischemia/reperfusion. While these effects are particularly pronounced during long-term administration, i.e., beyond $12-24 \mathrm{~h}$, several retrospective studies suggest that even hyperoxemia of shorter duration is also associated with increased mortality and morbidity. In fact, albeit the clinical evidence from prospective studies is surprisingly scarce, a recent meta-analysis suggests that hyperoxia is associated with increased mortality at least in patients after cardiac arrest, stroke and TBI [172]. Most of these data, however, originate from heterogenous, observational studies with inconsistent results, and therefore, there is a need for the results from the large scale, randomized, controlled clinical trials on the use of hyperoxia, which can be anticipated within the next 2-3 years. Consequently, until then, "...conservative..." $\mathrm{O}_{2}$ therapy [140] represents the treatment of choice to avoid exposure to both hypoxemia and excess hyperoxemia.

\section{Abbreviations}

ARDS: Acute Respiratory Distress Syndrome; ATP: adenosine triphosphate; CO: carbon monoxide; DCl: decompression injury; DCS: Decompression sickness; ECG: electrocardiogram; $\mathrm{FiO}_{2}$ : fraction of inspired oxygen; $\mathrm{Hb}$ : hemoglobin; HBO: hyperbaric oxygenation; ICP: intracranial pressure; ICU: intensive care unit; MI: myocardial infarction; MRI: magnetic resonance imaging; $\mathrm{N}_{2}$ : nitrogen; $\mathrm{NO}$ : nitric oxide; $\mathrm{O}_{2}$ : oxygen; $\mathrm{PaO}_{2}$ : arterial partial pressure of oxygen; $\mathrm{PCO}_{2}$ : partial pressure of carbon dioxide; PEEP: Positive end-expiratory pressure; $\mathrm{PO}_{2}$ : partial pressure of oxygen; RCT: randomized controlled trial; RNS: reactive nitrogen species; ROS: reactive oxygen species; ROSC: return of spontaneous circulation; SIRS: systemic inflammatory response syndrome; $\mathrm{SpO}_{2}$ : peripheral hemoglobin oxygen saturation; $T B I$ : traumatic brain injury; $V_{A} / Q$ : ventilation/ perfusion ratio; VILI: ventilator-induced lung injury.

\section{Authors' contributions}

$\mathrm{SH}, \mathrm{FB}$ carried out the literature review and helped to draft the manuscript. PR conducted the literature review and drafted the manuscript. PA helped to conduct the literature review and drafted the manuscript. AK reviewed the sub-chapter on "cerebral effects" and provided the material documenting the vascular effect of hyperbaric hyperoxia (Fig. 2). All authors read and approved the final manuscript.

\section{Author details}

${ }^{1}$ Institut für Anästhesiologische Pathophysiologie und Verfahrensentwicklung, Universitätsklinikum Ulm, Helmholtzstrasse 8-1, 89081 UIm, Germany. ${ }^{2}$ Klinik für Anästhesiologie, Universitätsklinikum Ulm, Albert-Einstein-Allee 23, 89081 Ulm, Germany. ${ }^{3}$ Département de Réanimation Médicale et de Médecine Hyperbare, Centre Hospitalier Universitaire, 4 rue Larrey, Cedex 9, 49933 Angers, France. ${ }^{4}$ Laboratoire de Biologie Neurovasculaire et Mitochondriale Intégrée, CNRS UMR 6214-INSERM U1083, Université Angers, PRES L'UNAM, Nantes, France. ${ }^{5}$ Sektion Maritime Medizin, Institut für Experimentelle Medizin, Christian-Albrechts-Universität, 24118 Kiel, Germany. ${ }^{6}$ Schifffahrtmedizinisches Institut der Marine, 24119 Kronshagen, Germany.

\section{Acknowledgements}

Supported by the Deutsche Forschungsgemeinschaft (KFO 200, DFG RA 396/9-2, and the SFB 1149) and the German MoD (Vertragsforschungsvorhaben E/U2AD/CF523/DF556).

Received: 4 August 2015 Accepted: 2 November 2015

Published online: 19 November 2015 


\section{References}

1. Leverve XM. To cope with oxygen: a long and still tumultuous story for life. Crit Care Med. 2008;36:637-8.

2. Jamieson D, Chance B, Cadenas E, Boveris A. The relation of free radical production to hyperoxia. Ann Rev Physiol. 1986;48:703-19.

3. Turrens JF. Mitochondrial formation of reactive oxygen species. J Physiol. 2003;552:335-44.

4. Magder S. Reactive oxygen species: toxic molecules or spark of life? Crit Care. 2006;10:208

5. Vincent JL, De Backer D. Circulatory shock. N Engl J Med. 2013:369:1726-34

6. Weil MH, Shubin H. The, "VIP" approach to the bedside management of shock. JAMA. 1969:207:337-40.

7. Yealy DM, Kellum JA, Huang DT, Barnato AE, Weissfeld LA, Pike F, et al. A randomized trial of protocol-based care for early septic shock. N Engl J Med. 2014;370:1683-93.

8. Oxer HF. Simply add oxygen: why isn't oxygen administration taught in all resuscitation training? Resuscitation. 2000;43:163-9.

9. Singer M. Give oxygen, get a blood pressure... but don't overdo it. Hosp Med. 2005;66:73-5.

10. Altemeier WA, Sinclair SE. Hyperoxia in the intensive care unit: why more is not always better. Curr Opin Crit Care. 2007:13:73-8.

11. Bitterman H. Bench-to-bedside review: oxygen as a drug. Crit Care. 2009;13:205

12. Calzia E, Asfar P, Hauser B, Matejovic M, Ballestra C, Radermacher P, et al. Hyperoxia may be beneficial. Crit Care Med. 2010;38:S559-68.

13. Cornet AD, Kooter AJ, Peters MJ, Smulders YM. The potential harm of oxygen therapy in medical emergencies. Crit Care. 2013;17:313.

14. Sjöberg F, Singer M. The medical use of oxygen: a time for critical reappraisal. J Intern Med. 2013;274:505-28.

15. Network The Acute Respiratory Distress Syndrome. Ventilation with lower tidal volumes as compared with traditional tidal volumes for acute lung injury and the acute respiratory distress syndrome. N Engl J Med. 2000;342:1301-8.

16. Asfar $P$, Singer M, Radermacher P. Understanding the benefits and harms of oxygen therapy. Intensive Care Med. 2015;41:1118-21.

17. Dellinger RP, Levy MM, Rhodes A, Annane D, Gerlach H, Opal SM, et al. Surviving sepsis campaign: International guidelines for management of severe sepsis and septic shock, 2012. Intensive Care Med. 2013:39:165-228.

18. Boerema I, Meyne NG, Brummelkamp WH, Bouma S, Mensch MH, Kamermans F, et al. Life without blood. Ned Tijdschr Geneeskd. 1960;104:949-54.

19. Takasu A, Iwamoto S, Ando S, Minagawa Y, Kashiba M, Yamamoto Y, et al. Effects of various concentrations of inhaled oxygen on tissue dysoxia, oxidative stress, and survival in a rat hemorrhagic shock model. Resuscitation. 2009;80:826-31.

20. Blasiole B, Bayr H, Vagni VA, Janesko-Feldman K, Cheikhi A, Wisniewski $\mathrm{SR}$, et al. Effect of hyperoxia on resuscitation of experimental combined traumatic brain injury and hemorrhagic shock in mice. Anesthesiology. 2013:118:649-63.

21. Takasu A, Prueckner S, Tisherman SA, Stezoski SW, Stezoski J, Safar P. Effects of increased oxygen breathing in a volume controlled hemorrhagic shock outcome model in rats. Resuscitation. 2000;45:209-20.

22. Kim SH, Stezoski SW, Safar P, Tisherman SA. Hypothermia, but not 100\% oxygen breathing, prolongs survival time during lethal uncontrolled hemorrhagic shock in rats. J Trauma. 1998:44:485-91.

23. Takasu A, Carrillo P, Stezoski SW, Safar P, Tisherman SA. Mild or moderate hypothermia but not increased oxygen breathing prolongs survival during lethal uncontrolled hemorrhagic shock in rats, with monitoring of visceral dysoxia. Crit Care Med. 1999;27:1557-64.

24. Leonov Y, Safar P, Sterz F, Stezoski SW. Extending the golden hour of hemorrhagic shock tolerance with oxygen plus hypothermia in awake rats. An exploratory study. Resuscitation. 2002;52:193-202.

25. Knöller E, Stenzel T, Broeskamp F, Hornung R, Scheuerle A, McCook O, et al. Effects of hyperoxia and mild therapeutic hypothermia during resuscitation from porcine hemorrhagic shock. Crit Care Med. 2016, in press.

26. Edmark L, Kostova-Aherdan K, Enlund M, Hedenstierna G. Optimal oxygen concentration during induction of general anesthesia. Anesthesiology. 2003;98:28-33.
27. Rothen HU, Sporre B, Engberg G, Wegenius G, Reber A, Hedenstierna A. Prevention of atelectasis during general anaesthesia. Lancet. 1995;345:1387-91.

28. Rothen HU, Sporre B, Engberg G, Wegenius G, Reber A, Hedenstierna G. Atelectasis and pulmonary shunting during induction of general anaesthesia-can they be avoided? Acta Anaesthesiol Scand. 1996;40:524-9.

29. Gunnarsson L, Tokics L, Gustavsson H, Hedenstierna G. Influence of age on atelectasis formation and gas exchange impairment during general anaesthesia. Br J Anaesth. 1991;66:423-32.

30. Strandberg A, Tokics L, Brismar B, Lundquist H, Hedenstierna G. Constitutional factors promoting development of atelectasis during anaesthesia. Acta Anaesthesiol Scand. 1987;31:21-4.

31. Gunnarsson L, Tokics L, Lundquist H, Brismar B, Strandberg A, Berg $B$, et al. Chronic obstructive pulmonary disease and anaesthesia: formation of atelectasis and gas exchange impairment. Eur Respir J. 1991;4:1106-16.

32. Horvat M, Yoshida S, Prakash R, Marcus HS, Swan HJ, Ganz W. Effect of oxygen breathing on pacing-induced angina pectoris and other manifestations of coronary insufficiency. Circulation. 1972;45:837-44

33. Ranchord AM, Perrin K, Weatherall M, Beasley R, Simmonds M. A randomised controlled trial of the effect of high concentration oxygen on myocardial ischaemia during exercise. Int J Cardiol. 2012;160:201-5.

34. Domino KB, Wetstein L, Glasser SA, Lindgren L, Marshall C, Harken A, et al. Influence of mixed venous oxygen tension ( $\left(\mathrm{P}_{\mathrm{O}_{2}}\right)$ on blood flow to atelectatic lung. Anesthesiology. 1983;59:428-34.

35. Sandoval J, Long GR, Skoog C, Wood LD, Oppenheimer L. Independent influence of blood flow rate and mixed venous $\mathrm{PO}_{2}$ on shunt fraction. J Appl Physiol. 1983;55:1128-33.

36. Hedenstierna $\mathrm{G}$. The hidden pulmonary dysfunction in acute lung injury. Intensive Care Med. 2006;32:1933-4.

37. Aboab J, Jonson B, Kouatchet A, Taille S, Niklason L, Brochard L. Effect of inspired oxygen fraction on alveolar derecruitment in acute respiratory distress syndrome. Intensive Care Med. 2006;32:1979-86.

38. Dantzker DR, Wagner PD, West JB. Instability of lung units with low $V_{A} / Q$ ratios during $\mathrm{O}_{2}$ breathing. J Appl Physiol. 1975;38:886-95.

39. Neumann P, Rothen HU, Berglund JE, Valtysson J, Magnusson A, Hedenstierna G. Positive end-expiratory pressure prevents atelectasis during general anaesthesia even in the presence of a high inspired oxygen concentration. Acta Anaesthesiol Scand. 1999;43:295-301.

40. Rusca M, Proietti S, Schnyder P, Frascarolo P, Hedenstierna G, Spahn DR, et al. Prevention of atelectasis formation during induction of general anesthesia. Anesth Analg. 2.

41. Carraway MS, Piantadosi CA. Oxygen toxicity. Respir Care Clin N Am. 1999;5:265-95.

42. Bornstein A. Ueber Sauerstoffvergiftung. Dtsch Med Wochenschr. 1912:43:1495-7.

43. Lorrain Smith J. The pathological effects due to increase of oxygen tension in the air breathed. J Physiol (London). 1899;24:19-35.

44. Lavoisier AL. Mémoires de Médecine et de Physique Médicale. Société de Médecine Royale: Paris 1783.

45. Kallett RH, Matthay MA. Hyperoxic acute lung injury. Respir Care. 2013;58:123-41

46. Eynan M, Krinsky N, Biram A, Aieli Y, Arieli R. A comparison of factors involoved in the development of central nervous system and pulmonary oxygen toxicity in the rat. Brains Res. 2014:1574:77-83.

47. Matute-Bello G, Frevert CW, Martin TR. Animal models of acute lung injury. Am J Physiol Lung Cell Mol Physiol. 2008;295:L379-99.

48. Crimi E, Sica V, Williams-Ignarro S, Zhang H, Slutsky AS, Ignarro LJ, Napoli C. The role of oxidative stress in adult critical care. Free Rad Biol Med. 2006:398-406.

49. Magder S. Reactive oxygen species: toxic molecules or spark of life? Crit Care. 2006:10:208

50. Zenri H, Rodriquez-Capote K, McCaig L, Yao LJ, Brackenbury A, Possmayer $F$, et al. Hyperoxia exposure impairs surfactant function and metabolism. Crit Care Med. 2004;32:1155-60.

51. Sinclair SE, Altemeier WA, Matute-Bello G, Chi EY. Augmented lung injury due to interaction between hyperoxia and mechanical ventilation. Crit Care Med. 2004;32:2496-501.

52. Wagner K, Gröger M, McCook O, Scheuerle A, Asfar P, Stahl B, et al. Blunt Chest trauma in mice after cigarette smoke-exposure: effects of mechanical ventilation with 100\% O2. PLoS One. 2015;10:e0132810. 
53. Cannizzaro V, Hantos Z, Sly PD, Zosky GR. Linking lung function and inflammatory responses in ventilator-induced lung injury. Am J Physio Lung Cell Mol Physiol. 2011;300:L112-20.

54. Barth E, Bassi G, Maybauer DM, Simon F, Groger M, Oter S, et al. Effects of ventilation with $100 \%$ oxygen during early hyperdynamic porcine fecal peritonitis. Crit Care Med. 2008;36:495-503.

55. Suttner $\mathrm{S}$, Boldt J. Routine use of high inspired oxygen concentrationcon. Anasthesiol Intensivmed Notfallmed Schmerzther. 2005;40:354-7.

56. Sackner MA, Landa J, Hirsch J, Zapata A. Pulmonary effects of oxygen breathing. A 6-hour study in normal men. Ann Intern Med. 1975;82:40-3.

57. Comroe JH, Dripps RD, Dumke PR, Deming M. Oxygen toxicity: the effect of inhalation of high concentrations of oxygen for twenty-four hours on normal men at sea level and at a simulated altitude of 18,000 feet. JAMA. 1945;128:710-7.

58. Kabon B, Kurz A. Optimal perioperative oxygen administration. Curr Opin Anaesthesiol. 2006;19:11-8.

59. Bean JW. Effects of oxygen at increased pressure. Physiol Rev. 1945;25:1-147.

60. Nash G, Blennerhassett JB, Pontoppidan H. Pulmonary lesions assocaited with oxygen therapy and artificial ventilation. N Engl J Med. 1967:276:368-74.

61. Hyde RW, Rawson AJ. Unintentional iatrogenic oxygen pneumonitisresponse to therapy. Ann Intern Med. 1969;71:517-31.

62. Gould VE, Tosco R, Wheelis RF, Gould NS, Kapanci Y. Oxygen pneumonitis in man. Ultrastructural observations on the development of alveolar lesions. Lab Invest. 1972;26:499-508.

63. Kapanci Y, Tosco R, Eggermann J, Gould VE. Oxygen pneumonitis in man. Light- and electron-microscopic morphometric studies. Chest. 1972;62:162-9.

64. Rachmale S, Li G, Wilson G, Malinchoc M, Gajic O. Practice of excessive $\mathrm{F}_{\mathrm{IO} 2}$ and effects on pulmonary outcomes in mechanically ventilated patients with acute lung injury. Respir Care. 2012;57:1887-93.

65. Elmer J, Wang B, Melhem S, Pullalarevu R, Vaghasia N, Buddineni J, et al Exposure to high concentrations of inspired oxygen does not worsen lung injury after cardiac arrest. Crit Care. 2015;19:105.

66. Hendricks PL, Hall DA, Hunter WL Jr, Haley PJ. Extension of pulmonary $\mathrm{O}_{2}$ tolerance in man at 2 ATA by intermittent $\mathrm{O}_{2}$ exposure. J Appl Physiol. 1977;42:593-9.

67. Whalen RE, Saltzman HA, Holloway DH Jr, Mclntosh HD, Sieker HO, Brown IW Jr. Cardiovascular and blood gas responses to hyperbaric oxygenation. Am J Cardiol. 1965:15:638-46.

68. Mak S, Azevedo ER, Liu PP, Newton GE. Effect of hyperoxia on left ventricular function and filling pressures in patients with and without congestive heart failure. Chest. 2001;120:467-73.

69. Mak S, Egri Z, Tanna G, Colman R, Newton GE. Vitamin C prevents hyperoxia-mediated vasoconstriction and impairment of endothelium-dependent vasodilation. Am J Physiol Heart Circ Physiol. 2002;282:H2414-21.

70. Reinhart K, Bloos F, Konig F, Bredle D, Hannemann L. Reversible decrease of oxygen consumption by hyperoxia. Chest. 1991;99:690-4.

71. Ellsworth ML, Forrester T, Ellis CG, Dietrich HH. The erythrocyte as a regulator of vascular tone. Am J Physiol. 1995:269:H2155-61.

72. Stamler JS, Jia L, Eu JP, McMahon TJ, Demchenko IT, Bonaventura J, et al. Blood flow regulation by S-nitrosohemoglobin in the physiological oxygen gradient. Science. 1997;276:2034-7.

73. McNulty PH, Robertson BJ, Tulli MA, Hess J, Harach LA, Scott S, et al. Effect of hyperoxia and vitamin C on coronary blood flow in patient with ischemic heart disease. J Appl Physiol. 1985;2007(102):2040-5.

74. Rossi P, Tauzin L, Weiss M, Rostain JC, Sainty JM, Boussuges A. Could hyperoxic ventilation impair oxygen delivery in septic patients? Clin Physiol Funct Imaging. 2007;27:180-4.

75. Farquhar $H$, Weatherall M, Wijesinghe $M$, Perrin $K$, Ranchord A, Simmonds $M$, et al. Systematic review of studies of the effect of hyperoxia on coronary blood flow. Am Heart J. 2009;158:371-7.

76. Cortés D, Puflea F, Donadello K, Taccone F, Gottin L, Creteur J, et al. Normobaric hyperoxia alters the microcirculation in healthy volunteers. Microvasc Res. 2015;98:23-8.

77. Bitterman H, Brod V, Weisz G, Kushnir D, Bitterman N. Effects of oxygen on regional hemodynamics in hemorrhagic shock. Am J Physiol. 1996:271:H203-11.
78. Stolmeijer R, ter Maaten JC, Zijlstra JG, Ligtenberg JJ. Oxygen therapy for sepsis patients in the emergency department: a little less? Eur J Emerg Med. 2014;21:233-5.

79. Schoonen WG, Wanamarta AH, van der Klei-van Moorsel JM, Jakobs C, Joenje $\mathrm{H}$. Hyperoxia-induced clonogenic killing of HeLa cells associated with respiratory failure and selective inactivation of Krebs cycle enzymes. Mutat Res. 1990;237:173-81.

80. Das KC. Hyperoxia decreases glycolytic capacity, glycolytic reserve and oxidative phosphorylation in MLE-12 cells and inhibits complex I and II function, but not complex IV in isolated mouse lung mitochondria. PLoS One. 2013;8:e73358.

81. Lauscher P, Lauscher S, Kertscho H, Habler O, Meier J. Hyperoxia reversibly alters oxygen consumption and metabolism. Scie World J. 2012;2012:410321

82. Reinhart K, Spies CD, Meier-Hellmann A, Bredle DL, Hannemann L, Specht $\mathrm{M}$, et al. $\mathrm{N}$-acetylcysteine preserves oxygen consumption and gastric mucosal pH during hyperoxic ventilation. Am J Respir Crit Care Med. 1995:151:773-9.

83. Ganz W, Donoso R, Marcus H, Swan HJ. Coronary hemodynamics and myocardial oxygen metabolism during oxygen breathing in patients with and without coronary artery disease. Circulation. 1972;45:763-8.

84. Leverve XM. Mitochondrial function and substrate availability. Crit Care Med. 2007;35:S454-60.

85. Korvald C, Elvenes OP, Myrmel T. Myocardial substrate metabolism influences left ventricular energetics in vivo. Am J Physiol Heart Circ Physiol. 2000;278:H1345-51.

86. Hochachka PW, Stanley C, Matheson GO, McKenzie DC, Allen PS, Parkhouse WS. Metabolic and work efficiencies during exercise in Andean natives. J Appl Physiol. 1985;1991(70):1720-30.

87. La Bert P. Pression Barométrique. Paris: Masson; 1878.

88. Demchenko IT, Moskvin AN, Krivchenko Al, Piantadosi CA, Allen BW. Nitric oxide-mediated central sympathetic excitation promotes CNS and pulmonary $\mathrm{O}_{2}$ toxicity. J Appl Physiol. 2012;112:1814-23.

89. Koch AE, Kähler W, Wegner-Bröse H, Weyer D, Kuhtz-Buschbeck J, Deuschl G, et al. Monitoring of CBFV and time characteristics of oxygeninduced acute CNS toxicity in humans. Eur J Neurol. 2008;15:746-8.

90. Bitterman N, Bitterman H. L-Arginine-NO pathway and CNS oxygen toxicity. J Appl Physiol. 1998;84:1633-8.

91. Roth D, Schreiber W, Herkner H, Havel C. Prevalence of carbon monoxide poisoning in patients presenting to a large emergency department. Int J Clin Pract. 2014;68:1239-45.

92. Ernst A, Zibrak JD. Carbon monoxide poisoning. N Engl J Med. 1998;339:1603-8.

93. Miro O, Alonso JR, Casademont J, Jarreta D, Urbano-Marquez A, Cardellach F. Oxidative damage on lymphocyte membranes is increased in patients suffering from acute carbon monoxide poisoning. Toxicol Lett. 1999;110:219-23.

94. Stamler JS, Piantadosi CA. O=O NO: it's CO. J Clin Invest. 1996:97:2165-6.

95. Weaver LK, Howe S, Hopkins R, Chan KJ. Carboxyhemoglobin half-life in carbon monoxide-poisoned patients treated with $100 \%$ oxygen at atmospheric pressure. Chest. 2000;117:801-8.

96. Annane D, Chadda K, Gajdos P, Jars-Guincestre MC, Chevret S, Raphael JC. Hyperbaric oxygen therapy for acute domestic carbon monoxide poisoning: two randomized controlled trials. Intensive Care Med. 2011;37:486-92

97. Weaver LK, Hopkins RO, Chan KJ, Churchill S, Elliott CG, Clemmer TP, et al. Hyperbaric oxygen for acute carbon monoxide poisoning. N Engl J Med. 2002;347:1057-67.

98. Scheinkestel CD, Bailey M, Myles PS, Jones K, Cooper DJ, Millar IL, et al. Hyperbaric or normobaric oxygen for acute carbon monoxide poisoning: a randomised controlled clinical trial. Med J Aust. 1999;170:203-10.

99. Chiew AL, Buckley NA. Carbon monoxide poisoning in the 21 st century. Crit Care. 2014;18:221.

100. Muth CM, Shank ES. Gas embolism. N Engl J Med. 2000;342:476-82.

101. Vann RD, Butler FK, Mitchell SJ, Moon RE. Decompression illness. Lancet. 2011;377:153-64.

102. Tetzlaff K, Shank ES, Muth CM. Evaluation and management of decompression illness-an intensivist's perspective. Intensive Care Med. 2003:29:2128-36. 
103. Muth CM, Shank ES, Larsen B. Severe diving accidents: physiopathology, symptoms, therapy. Anaesthesist. 2000;49:302-16.

104. Boland EW. Oxygen in high concentrations for relief of pain in coronary thrombosis and severe angina pectoris. JAMA. 1940;114:1512-4.

105. McNulty PH, King N, Scott S, Hartman G, McCann J, Kozak M, et al. Effects of supplemental oxygen administration on coronary blood flow in patients undergoing cardiac catheterization. Am J Physiol Heart Circ Physiol. 2005;288:H1057-62.

106. Kones R. Oxygen therapy for acute myocardial infarction-then and now. A century of uncertainty. Am J Med. 2011;124:1000-5.

107. Shuvy M, Atar D, Gabriel Steg P, Halvorsen S, Jolly S, Yusuf S, et al. Oxygen therapy in acute coronary syndrome: are the benefits worth the risk? Eur Heart J. 2013;34:1630-5.

108. Minana G, Nunez J, Banuls P, Sanchis J, Nunez E, Robles R, et al. Prognostic implications of arterial blood gases in acute decompensated heart failure. Eur J Intern Med. 2011;22:489-94.

109. HR, Bossaert LL, Danchin N, Nikolaou NI. European Resuscitation Council Guidelines for Resuscitation 2010 Section 5. Initial management of acute coronary syndromes. Resuscitation. 2010;81:1353-63.

110. Madias JE, Madias NE, Hood WB Jr. Precordial ST-segment mapping. 2. Effects of oxygen inhalation on ischemic injury in patients with acute myocardial infarction. Circulation. 1976;53:411-7.

111. Rawles JM, Kenmure AC. Controlled trial of oxygen in uncomplicated myocardial infarction. Br Med J. 1976;1:1121-3.

112. Ukholkina GB, Kostyanov IY, Kuchkina NV, Grendo EP, Gofman YB. Oxygen therapy in combination with endovascular reperfusion during the first hours of acute myocardial infarction: clinical and laboratory findings. Int J Interv Cardioangiol. 2005;9:45-51.

113. Ranchord AM, Argyle R, Beynon R, Perrin K, Sharma V, Weatherall M, et al. High-concentration versus titrated oxygen therapy in ST-elevation myocardial infarction: a pilot randomized controlled trial. Am Heart J. 2012;163:168-75.

114. Stub D, Smith K, Bernard S, Nehme Z, Stephenson M, Bray JE, et al. Air versus oxygen in ST-segment elevation myocardial infarction. Circulation. 2015;131:2143-50.

115. Rockswold SB, Rockswold GL, Zaun DA, Zhang X, Cerra CE, Bergman TA, et al. A prospective, randomized clinical trial to compare the effect of hyperbaric to normobaric hyperoxia on cerebral metabolism, intracranial pressure, and oxygen toxicity in severe traumatic brain injury. J Neurosurg. 2010;112:1080-94.

116. Rockswold SB, Rockswold GL, Zaun DA, Liu J. A prospective, randomized Phase II clinical trial to evaluate the effect of combined hyperbaric and normobaric hyperoxia on cerebral metabolism, intracranial pressure, oxygen toxicity, and clinical outcome in severe traumatic brain injury. J Neurosurg. 2013;118:1317-28.

117. Magnoni S, Ghisoni L, Locatelli M, Caimi M, Colombo A, Valeriani V, et al. Lack of improvement in cerebral metabolism after hyperoxia in severe head injury: a microdialysis study. J Neurosurg. 2003;98:952-8.

118. Tolias CM, Reinert M, Seiler R, Gilman C, Scharf A, Bullock MR. Normobaric hyperoxia-induced improvement in cerebral metabolism and reduction in intracranial pressure in patients with severe head injury: a prospective historical cohort-matched study. J Neurosurg. 2004:101:435-44.

119. Diringer MN, Aiyagari V, Zazulia AR, Videen TO, Powers WJ. Effect of hyperoxia on cerebral metabolic rate for oxygen measured using positron emission tomography in patients with acute severe head injury. J Neurosurg. 2007;106:526-9.

120. Hlatky R, Valadka AB, Gopinath SP, Robertson CS. Brain tissue oxygen tension response to induced hyperoxia reduced in hypoperfused brain. J Neurosurg. 2008;108:53-8.

121. Nortje J, Coles JP, Timofeev I, Fryer TD, Aigbirhio FI, Smielewski P, et al. Effect of hyperoxia on regional oxygenation and metabolism after severe traumatic brain injury: preliminary findings. Crit Care Med. 2008;36:273-81.

122. Quintard H, Patet C, Suys T, Marques-Vidal P, Oddo M. Normobaric hyperoxia is associated with increased cerebral excitotoxicity after severe traumatic brain injury. Neurocrit Care. 2015;22:243-50.

123. Veenith TV, Carter EL, Grossac J, Newcombe VF, Outtrim JG, Nallapareddy $S$, et al. Use of diffusion tensor imaging to assess the impact of normobaric hyperoxia within at-risk pericontusional tissue after traumatic brain injury. J Cereb Blood Flow Metab. 2014;34:1622-7.
124. Narotam PK. Eubaric hyperoxia: controversies in the management of acute traumatic brain injury. Crit Care. 2013;17:197.

125. Raj R, Bendel S, Reinikainen M, Kivisaari R, Siironen J, Lang M, et al. Hyperoxemia and long-term outcome after traumatic brain injury. Crit Care. 2013;17:R177.

126. Davis DP, Meade W, Sise MJ, Kennedy F, Simon F, Tominaga G, et al. Both hypoxemia and extreme hyperoxemia may be detrimental in patients with severe traumatic brain injury. J Neurotrauma. 2009;26:2217-23.

127. Brenner M, Stein D, Hu P, Kufera J, Wooford M, Scalea T. Association between early hyperoxia and worse outcomes after traumatic brain injury. Arch Surg. 2012;147:1042-6

128. Rincon F, Kang J, Vibbert M, Urtecho J, Athar MK, Jallo J. Significance of arterial hyperoxia and relationship with case fatality in traumatic brain injury: a multicentre cohort study. J Neurol Neurosurg Psychiatry. 2014;85:799-805.

129. Asher SR, Curry P, Sharma D, Wang J, O'Keefe GE, Daniel-Johnson J, et al. Survival advantage and $\mathrm{PaO}_{2}$ threshold in severe traumatic brain injury. J Neurosurg Anesthesiol. 2013;25:168-73.

130. Qi Z, Liu W, Luo Y, Ji X, Liu KJ. Normobaric hyperoxia-based neuroprotective therapies in ischemic stroke. Med Gas Res. 2013;3:2.

131. Singhal AB, Benner T, Roccatagliata L, Koroshetz WJ, Schaefer PW, LO $\mathrm{EH}$, et al. A pilot study of normobaric oxygen therapy in acute ischemic stroke. Stroke. 2005;36:797-802.

132. Singhal AB, Ratai E, Benner T, Vangel M, Lee V, Koroshetz WJ, et al Magnetic resonance spectroscopy study of oxygen therapy in ischemic stroke. Stroke. 2007;38:2851-4.

133. Jeon SB, Choi HA, Badjatia N, Schmidt JM, Lantigua H, Claassen J, et al. Hyperoxia may be related to delayed cerebral ischemia and poor outcome after subarachnoid haemorrhage. J Neurol Neurosurg Psychiatry. 2014;85:1301-7

134. Rincon F, Kang J, Maltenfort M, Vibbert M, Urtecho J, Athar MK, et al. Association between hyperoxia and mortality after stroke: a multicenter cohort study. Crit Care Med. 2014:42:387-96.

135. Young P, Beasley R, Bailey M, Bellomo R, Eastwood GM, Nichol A, et al. The association between early arterial oxygenation and mortality in ventilated patients with acute ischaemic stroke. Crit Care Resusc. 2012:14:14-9.

136. Roffe C, Ali K, Warusevitane A, Sills S, Pountain S, Allen M, et al. The SOS pilot study: a RCT of routine oxygen supplementation early after acute stroke-effect on recovery of neurological function at one week. PLoS One. 2011;6:e19113.

137. Ali K, Warusevitane A, Lally F, Sim J, Sills S, Pountain S, et al. The stroke oxygen pilot study: a randomized controlled trial of the effects of routine oxygen supplementation early after acute stroke-effect on key outcomes at 6 months. PLoS One. 2013;8:e59274.

138. Kilgannon JH, Jones AE, Shapiro NI, Angelos MG, Milcarek B, Hunter K, et al. Association between arterial hyperoxia following resuscitation from cardiac arrest and in-hospital mortality. JAMA. 2010;303:2165-71.

139. Kilgannon JH, Jones AE, Parrillo JE, Dellinger RP, Milcarek B, Hunter K, et al. Relationship between supranormal oxygen tension and outcome after resuscitation from cardiac arrest. Circulation. 2011;123:2717-22.

140. Bellomo R, Bailey M, Eastwood GM, Nichol A, Pilcher D, Hart GK, et al. Arterial hyperoxia and in-hospital mortality after resuscitation from cardiac arrest. Crit Care. 2011;15:R90.

141. Ihle JF, Bernard S, Bailey MJ, Pilcher DV, Smith K, Scheinkestel CD. Hyperoxia in the intensive care unit and outcome after out-ofhospital ventricular fibrillation cardiac arrest. Crit Care Resusc. 2013;15:186-90.

142. Nelskylä A, Parr MJ, Skrifvars MB. Prevalence and factors correlating with hyperoxia exposure following cardiac arrest-an observational single centre study. Scand J Trauma Resusc Emerg Med. 2013;21:35.

143. Janz DR, Hollenbeck RD, Pollock JS, McPherson JA, Rice TW. Hyperoxia is associated with increased mortality in patients treated with mild therapeutic hypothermia after sudden cardiac arrest. Crit Care Med. 2012;40:3135-9.

144. Lee BK, Jeung KW, Lee HY, Lee SJ, Jung YH, Lee WK, et al. Association between mean arterial blood gas tension and outcome in cardiac arrest patients treated with therapeutic hypothermia. Am J Emerg Med. 2014;32:55-60.

145. Kuisma M, Boyd J, Voipio V, Alaspaa A, Roine RO, Rosenberg P. Comparison of 30 and the $100 \%$ inspired oxygen concentrations during 
early post-resuscitation period: a randomised controlled pilot study. Resuscitation. 2006;69:199-206.

146. Schneider AG, Eastwood GM, Bellomo R, Bailey M, Lipcsey M, Pilcher $D$, et al. Arterial carbon dioxide tension and outcome in patients admitted to the intensive care unit after cardiac arrest. Resuscitation. 2013;84:927-34.

147. Roberts BW, Kilgannon JH, Chansky ME, Mittal N, Wooden J, Trzeciak $\mathrm{S}$. Association between postresuscitation partial pressure of arterial carbon dioxide and neurological outcome in patients with post-cardiac arrest syndrome. Circulation. 2013;127:2107-13.

148. Vaahersalo J, Bendel S, Reinikainen M, Kurola J, Tiainen M, Raj R, et al. Arterial blood gas tensions after resuscitation from out-of-hospital cardiac arrest: associations with long-term neurologic outcome. Crit Care Med. 2014;42:1463-70.

149. Wang $\mathrm{CH}$, Chang WT, Huang $\mathrm{CH}$, Tsai MS, Yu PH, Wang AY, et al. The effect of hyperoxia on survival following adult cardiac arrest: a systematic review and meta-analysis of observational studies. Resuscitation. 2014;85:1142-8.

150. Elmer J, Scutella M, Pullalarevu R, Wang B, Vaghasia N, Trzeciak S, et al. The association between hyperoxia and patient outcomes after cardiac arrest: analysis of a high-resolution database. Intensive Care Med. 2015:41:49-57.

151. Young P, Bailey M, Bellomo R, Bernard S, Dicker B, Freebairn R, et al. HyperOxic Therapy OR NormOxic Therapy after out-of-hospital cardiac arrest (HOT OR NOT): a randomised controlled feasibility trial. Resuscitation. 2014;85:1686-91.

152. Knighton DR, Halliday B, Hunt TK. Oxygen as an antibiotic. The effect of inspired oxygen on infection. Arch Surg. 1984;119:199-204.

153. Togioka B, Galvagno S, Sumida S, Murphy J, Ouanes JP, Wu C. The role of perioperative high inspired oxygen therapy in reducing surgical site infection: a meta-analysis. Anesth Analg. 2012;114:334-42.

154. Hovaguimian F, Lysakowski C, Elia N, Tramer MR. Effect of intraoperative high inspired oxygen fraction on surgical site infection, postoperative nausea and vomiting, and pulmonary function: systematic review and meta-analysis of randomized controlled trials. Anesthesiology. 2013;119:303-16.

155. Schietroma M, Cecilia EM, Sista F, Carlei F, Pessia B, Amicucci G. Highconcentration supplemental perioperative oxygen and surgical site infection following elective colorectal surgery for rectal cancer: a prospective, randomized, double-blind, controlled, single-site trial. Am J Surg. 2014;208:719-26.

156. Kotani N, Hashimoto H, Sessler DI, Muraoka M, Hashiba E, Kubota T, et al. Supplemental intraoperative oxygen augments antimicrobial and proinflammatory responses of alveolar macrophages. Anesthesiology. 2000;93:15-25.

157. Qadan M, Battista C, Gardner SA, Anderson G, Akca O, Polk HC Jr. Oxygen and surgical site infection: a study of underlying immunologic mechanisms. Anesthesiology. 2010;113:369-77.

158. Meyhoff CS, Jorgensen LN, Wetterslev J, Christensen KB, Rasmussen LS. Increased long-term mortality after a high perioperative inspiratory oxygen fraction during abdominal surgery: follow-up of a randomized clinical trial. Anesth Analg. 2012;115:849-54.
159. Meyhoff CS, Jorgensen LN, Wetterslev J, Siersma VD, Rasmussen LS. Risk of new or recurrent cancer after a high perioperative inspiratory oxygen fraction during abdominal surgery. Br J Anaesth. 2014;113(Suppl 1):i74-81.

160. Meyhoff CS, Wetterslev J, Jorgensen LN, Hennebegr SW, Hogdall C, Lundvall $L$, et al. Effect of high perioperative oxygen fraction on surgical site infection and pulmonary complications after abdominal surgery. JAMA. 2009;302:1543-50.

161. Kurz A, Fleischmann E, Sessler DI, Buggy DJ, Apfel C, Akça O, et al. Effects of supplemental oxygen and dexamethasone on surgical site infection: a factorial randomized trial. Br J Anaesth. 2015;115:434-43.

162. Wetterslev J, Meyhoff CS, Jørgensen LN, Gluud C, Lindschou J, Rasmussen LS. The effect of high perioperative inspiratory oxygen fraction for adult surgical patients (review). Cochrane Database Syst Rev. 2015;6:CD008884

163. de Jonge $E$, Peelen L, Keijzers PJ, Joore H, de Lange D, van der Voort PH, et al. Association between administered oxygen, arterial partial oxygen pressure and mortality in mechanically ventilated intensive care unit patients. Crit Care. 2008;12:R156.

164. Helmerhorst HJ, Roos-Blom MJ, van Westerloo DJ, Abu-Hanna A, de Keizer NF, de Jonge E. Associations of arterial carbon dioxide and arterial oxygen concentrations with hospital mortality after resuscitation from cardiac arrest. Crit Care. 2015;19:348.

165. Eastwood G, Bellomo R, Bailey M, Taori G, Pilcher D, Young P, et al. Arterial oxygen tension and mortality in mechanically ventilated patients. Intensive Care Med. 2012;38:91-8.

166. Sutton AD, Bailey M, Bellomo R, Eastwood GM, Pilcher DV. The association between early arterial oxygenation in the ICU and mortality following cardiac surgery. Anaesth Intensive Care. 2014;42:730-5.

167. Damiani E, Adrario E, Girardis M, Romano R, Pelaia P, Singer M, et al. Arterial hyperoxia and mortality in critically ill patients: a systematic review and meta-analysis. Crit Care. 2014;18:711.

168. Helmerhorst HJ, Roos-Blom MJ, van Westerloo DJ, de Jonge E. Association between arterial hyperoxia and outcome in subsets of critical illness: a systematic review, metaanalysis, and meta-regression of cohort studies. Crit Care Med. 2015;43:1508-19.

169. Helmerhorst HJ, Schultz MJ, van der Voort PH, Bosman RJ, Juffermans $N P$, de Jonge $E$, et al. Self-reported attitudes versus actual practice of oxygen therapy by ICU physicians and nurses. Ann Intensive Care. 2014:4:23.

170. Rixen D, Siegel JH. Bench-to-bedside review: oxygen debt and its metabolic correlates as quantifiers of the severity of hemorrhagic and post-traumatic shock. Crit Care. 2005;9:441-53.

171. Barbee RW, Reynolds PS, Ward KR. Assessing shock resuscitation strategies by oxygen debt repayment. Shock. 2010;33:113-22.

172. Suzuki S, Eastwood GM, Glassford NJ, Peck L, Young H, Garcia-Alvarez M, et al. Conservative oxygen therapy in mechanically ventilated patients: a pilot before-and-after trial. Crit Care Med. 2014;42:1414-22.

\section{Submit your manuscript to a SpringerOpen ${ }^{\circ}$ journal and benefit from:}

- Convenient online submission

- Rigorous peer review

- Immediate publication on acceptance

- Open access: articles freely available online

- High visibility within the field

- Retaining the copyright to your article

Submit your next manuscript at $>$ springeropen.com 